Original scientific paper

\title{
MODELLING AND SIMULATION ON CAVITY COLD PLATE FOR LI-ION BATTERY THERMAL MANAGEMENT
}

\author{
Wang, T.*; Zhang, X.*\#; Zeng, Q. L. ${ }^{* *}$; Jiang, S. B.* \& Zhang, Y. N. ${ }^{* * *}$ \\ ${ }^{*}$ College of Mechanical and Electronic Engineering, Shandong University of Science and Technology, \\ Qingdao, 266590, China \\ ${ }^{* *}$ College of Information Science and Engineering, Shandong Normal University, Jinan, 250358, \\ China \\ ${ }^{* * *}$ Faculty of Mechanical Engineering, Czech Technical University in Prague, Prague 6, 16000, \\ Czech Republic \\ E-Mail: zhangxinmt@163.com ( ${ }^{\#}$ Corresponding author)
}

\begin{abstract}
Recently, the safety of electric vehicles using lithium-ion batteries has received increased attention due to overheating. Cold plates can effectively enhance heat dissipation. However, given the defects of existing cold plates, such as complex structure and heavy weight, a simple cavity cold plate is designed. The effects of cold plate inlet and outlet sizes $\left(d_{2}\right.$ and $\left.\Delta d\right)$, mass flow rate of coolant $(W)$, and the inlet and outlet position on cell's maximum temperature and temperature difference are analysed using computational fluid dynamics (CFD) to enhance the heat dissipation capacity of the cold plate. Results show that the inlet and outlet sizes are positively correlated with the cell's maximum temperature. In addition, the cavity cold plate can satisfy the requirements of battery temperature difference by optimizing the inlet and outlet sizes and $W$. The cooling system of Model $\mathrm{Z}$ has better heat dissipation capacity than that of Model N. Conclusions obtained in the study have important reference for optimization of cavity cold plates.

(Received in November 2021, accepted in January 2022. This paper was with the authors 1 month for 1 revision.)
\end{abstract}

Key Words: Cold Plate Modelling, Thermal Simulation, Battery Thermal Management, CFD

\section{INTRODUCTION}

In recent years, green vehicles, such as electric vehicles (EVs), have been rapidly developing, thereby offering an important approach to solve the global problems of energy crisis and environmental degradation [1,2]. EVs have the advantages of zero-emission [3], low noise, high efficiency, and low cost because they use clean energy as power source. However, with the growth of EVs' ownership and mileage, the safety of EV battery packs has attracted increased public attention $[4,5]$.

Lithium-ion (Li-ion) batteries are advantageous in terms of high energy density, long cycle life, low self-discharge rate, good stability and low pollution [6]. Thus, most energy storage devices of EVs adopt lithium-ion batteries. When Li-ion battery cell is discharged at a high rate, its temperature rises rapidly. If its temperature is extremely high, then the cell's capacity is reduced. Gas is generated inside the Li-ion battery, and the cell's body swells or smokes. In more serious cases, the battery burns or explodes, seriously endangering the users' safety [7]. In addition, when cell temperature difference is extremely large, the consistency of cell is reduced, and its service life is shortened [8]. Thus, to increase the safety and service life of Liion batteries, battery thermal management system (BTMS) is greatly important. A reasonable BTMS should maintain the cell temperature at $25-40{ }^{\circ} \mathrm{C}$ during charging and discharging, and the temperature difference should be controlled within $5{ }^{\circ} \mathrm{C}$. In addition, BTMS should have the advantages of small size, low energy consumption, good stability, and economy. Therefore, reasonable optimization is necessary [9]. 


\section{STATE OF THE ART}

BTMS cooling methods mostly involve the following parts: air cooling, liquid cooling, phase change materials (PCM), and heat pipes [10]. Many scholars have studied duct and air inflow of BTMS because air cooling is advantageous in simple structure, low cost, and low weight $[11,12]$. However, air cooling is rather restrictive. Air has low specific heat capacity and thermal conductivity, which is not conducive to large-scale applications. In terms of PCM, BTMSs are mainly optimized by increasing the thermal conductivity of PCM. PCM with better physical properties is selected, and the heat dissipation of PCM is enhanced [13]. However, the BTMS of PCM has high quality, high cost, and poor safety; thus, it is less practical in EVs. In all thermal management methods, heat pipe is relatively new but technologically imperfect. However, heat pipe has the advantages of small size, safety and reliability, high heat dissipation efficiency, and no energy consumption. Therefore, many scholars have applied heat pipes to heat dissipation of Li-ion batteries $[14,15]$. Only by solving the problems of high cost and technical difficulty of heat pipes can heat pipes truly exert their advantages.

Liquid cooling has a better development prospect than these thermal management methods. Liquid cooling, especially cold plate cooling, has the advantages of good heat transfer efficiency, heat dissipation, safety, stability, and economy. In addition, the simulation method based on experimental data can analyse the cooling effects of BTMS [16]. The existing cold plate cooling schemes mainly use mini-channel cold plates. The heat dissipation of cold plate has been enhanced by optimizing the flow distribution inside the cold plate [17]. For example, $\mathrm{Li}$ et al. [18] analysed four cold plates with different internal structures for heat dissipation of prismatic batteries. However, the mini-channel cold plate is more complicated and difficult to manufacture. In addition, most cold plates are made of aluminium with good physical properties. BTMS effects can also be enhanced by changing the cold plate materials. Li et al. [19] used silicon cold plates to analyse heat dissipation of prismatic batteries. However, compared with aluminium cold plates, silicon cold plates have high cost and low strength. In terms of coolants, compared with conventional coolants, such as water, oil, and aqueous solution of ethylene glycol (EGW), more scholars have studied novel coolants, such as nanofluids, liquid metals, and phase change fluids. Huo and Rao [20] studied the impacts of nanofluids on the temperature of high-power Li-ion battery. Their results showed that the addition of nanoparticles could reduce the maximum temperature of battery, with limited impacts on temperature uniformity. Yang et al. [21] compared the effects of liquid metal cooling and water cooling on heat dissipation of Li-ion batteries with different discharge rates. AlZareer et al. [22] used R134a phase change fluid to perform boiling cooling on battery pack under 5 C-rate (discharge rate) discharge by modelling and simulation. Although the physical parameters of these new coolants are better, their costs are higher, and some coolants are less environmentally friendly. In addition, a number of BTMS with different cooling methods have been designed, such as BTMS combined with phase change materials and cold plates, to enhance the heat transfer and improve battery temperature uniformity [22]. Composite-heat dissipation schemes have better thermal management effects than the single-heat dissipation schemes. However, they are more complicated in structure, greater in technical difficulty, and poorer in safety and stability.

In summary, cold plate BTMS has better performance and practicability than other BTMSs. Aluminium cold plates are more cost-effective, considering heat dissipation capacity and cost of cold plates. At the same time, due to its low freezing point, the aqueous solution of ethylene glycol can expand the minimum ambient temperature range for using cold plate BTMS. Existing cold plates have complicated the internal flow channel structure to achieve better cooling effects. Although this structure can enhance the heat dissipation capacity of BTMS, they also increase the difficulty of manufacturing together with cost. In response to these 
problems, a cavity cold plate for heat dissipation of Li-ion batteries is studied. The cold plate is advantageous in simple structure, small weight, and low energy consumption. When the discharge rate of pouch Li-ion battery is $4 \mathrm{C}$-rate, the effects of multiple variables on Li-ion cells are analysed.

The following parts are organized as follows. Part 3 introduces the physical model of cavity cold plate BTMS in detail. The sizes of the 3D model and specific parameters of Li-ion battery cells are provided. A heat generation model is established based on battery heat generation experimental data. The grid independence of BTMS model is tested, and the simulation setting is introduced in detail. The simulation results are discussed in detail in Part 4. Conclusions are presented in the fifth section.

\section{METHODOLOGY}

\subsection{Physical model}

Fig. 1 shows the battery cooling system of cavity cold plate. The cells in the cooling system are produced by Shandong RealForce Enterprises Co., Ltd. in China and outer surface by Al-Plastic Film. The 3D model is simplified using FLUENT17.0 for simulation. The effects of cold plate body on heat dissipation of cells' body are mainly studied. The external dimensions of cold plate are consistent with the sizes of cells. $d_{1}$ is the thickness of cold plate. $d_{2}$ is the width of inlet and outlet. $\Delta d$ is the difference between $d_{1}$ and $d_{2}$.

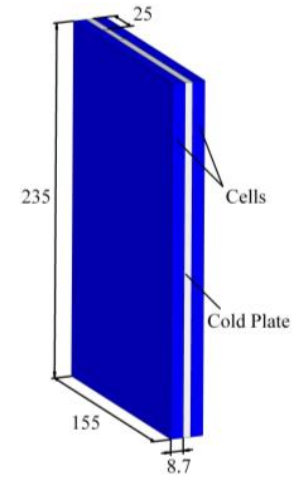

a) battery cooling system structure

Figure 1: Battery cooling system.

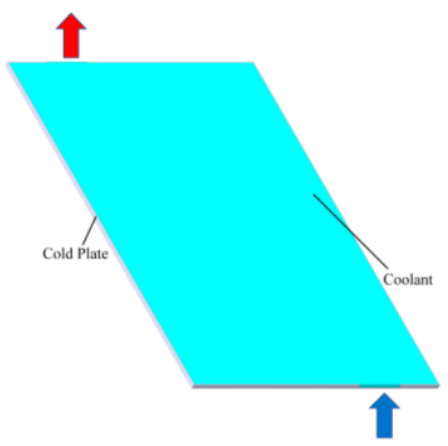

a) Model $\mathrm{N}$

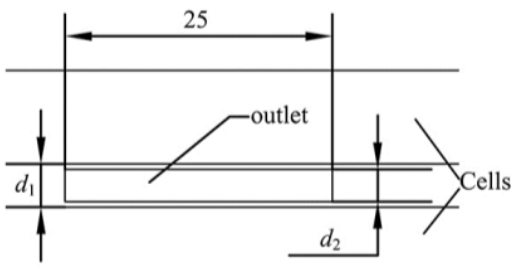

b) inlet and outlet dimensions

Figure 2: Flow of coolant in Model $\mathrm{N}$ and Model $\mathrm{Z}$ cold plates.

The coolant flow inside the cavity cold plate is shown in Fig. 2. The aluminium shell thickness of the cold plate is uniform at $0.5 \mathrm{~mm}$, with coolant inside. The weight of the cavity cold plate is lighter than that of the other conventional cold plates with the same volume because the density of aluminium is greater than that of the coolant. The diagonally opposite inlet and 
outlet of the cold plate are arranged on different sides. The layout of the inlet and outlet cold plate is changed; they are divided into two types, namely, Model $\mathrm{N}$ and Model Z. At the same time, by charging the inlet and outlet dimensions $\left(d_{1}\right.$ and $\left.d_{2}\right)$, each type of cold plate is divided into seven cold plates. The specific cold plate inlet and outlet dimensions are shown in Table I.

Table I: Dimensions $d_{1}$ and $d_{2}$ of different models.

\begin{tabular}{|c|c|c|c|c|c|c|c|}
\cline { 2 - 8 } \multicolumn{1}{c|}{} & Model 1 & Model 2 & Model 3 & Model 4 & Model 5 & Model 6 & Model 7 \\
\hline$d_{1}(\mathrm{~mm})$ & 2 & 3 & 4 & 5 & 3 & 4 & 5 \\
\hline$d_{2}(\mathrm{~mm})$ & 1 & 1 & 1 & 1 & 2 & 3 & 4 \\
\hline
\end{tabular}

\subsection{Heat generation model of cell with experiment data}

Combined with the actual working conditions of EVs, the cell is tested for heat generation when it is discharged at $4 \mathrm{C}$-rate, and the maximum temperature of the cell is obtained. According to the experimental data, User Define Function (UDF) in FLUENT is used to define cell's heat generation density, which can be estimated in Eq. (1), as follows:

$$
q=-63 t+93957.8
$$

where $q$ is the average heat generation density of cell $\left(\mathrm{W} / \mathrm{m}^{3}\right) . t$ is time (s).

Fig. 3 shows the maximum temperature in the heat generation experiment and simulation, from which the relative error is lower than $2 \%$.

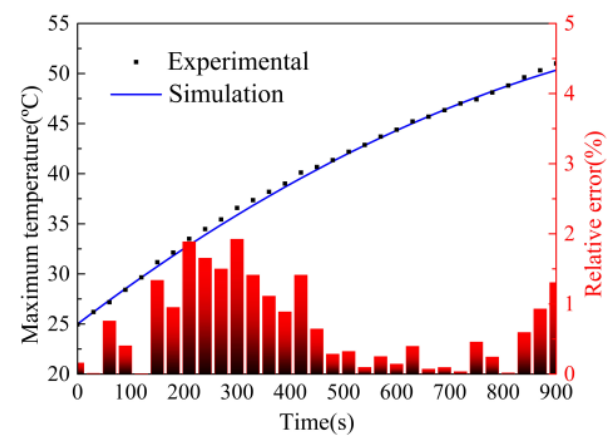

Figure 3: Comparison of cell heat generation experiment and simulation.

\subsection{Meshing and grid independence test}

All models are meshed by ICEM CFD 17.0. Grid independence test is carried out because the number and quality of the grids affect the simulation results, as shown in Fig. 4. The models in this study are similar; thus, the hexahedral mesh of Model $\mathrm{N}_{7}$ and Model $\mathrm{Z}_{7}$ is carried out. The grid number is 889248 to 6723820 , and the mass flow rate $(W)$ at cold plate inlet is $0.001 \mathrm{~kg} / \mathrm{s}$. When the number of grids is more than 5544176, the thermal transfer rate begins to stabilize in Fig. 4. Therefore, the number of all cooling system meshes is approximately 5.5 million. The quality of all meshes is greater than 0.9 .

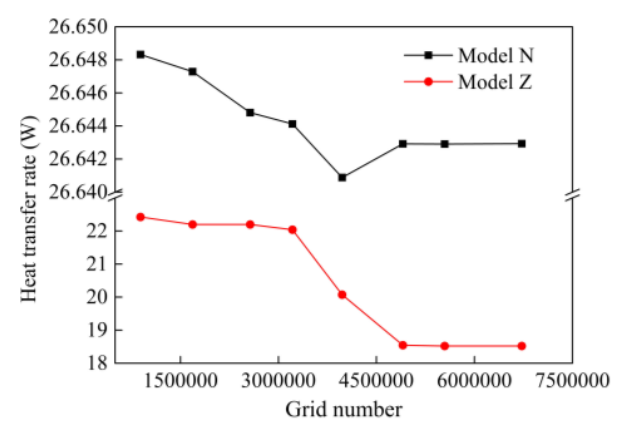

Figure 4: Model N and Model Z cold plate models grid independence test. 


\subsection{Simulation settings}

The Reynolds numbers of all cooling systems are calculated in the range of 101.72 to 567.28. Laminar Viscous Model is selected because the Reynolds numbers $(R e)$ of the cooling system are less than 2300. The slip of the coolant relative to inner surface of cavity cold plate and the thermal contact resistance in cooling systems are ignored. The inlet boundary type is mass flow inlet, and the outlet boundary type is outflow. The mass flow rates are set to $0.005,0.01,0.015$, 0.02 and $0.025 \mathrm{~kg} / \mathrm{s}$. The initial temperature of the coolant is $25^{\circ} \mathrm{C}$. Cells and cold plate to air contact surfaces are set to convection thermal condition, and the heat transfer coefficient and free stream temperature to $5 \mathrm{~W} /\left(\mathrm{m}^{2} \cdot \mathrm{K}\right)$ and $25^{\circ} \mathrm{C}$, respectively. The thermophysical parameters of the material in simulation are shown in Table II [23].

Table II: Thermal properties of materials.

\begin{tabular}{|l|c|c|c|c|}
\hline \multicolumn{1}{|c|}{ Material } & $\begin{array}{c}\text { Density } \\
\left(\mathrm{kg} / \mathrm{m}^{3}\right)\end{array}$ & $\begin{array}{c}\text { Heat capacity } \\
(\mathrm{J} / \mathrm{kg} \cdot \mathrm{K})\end{array}$ & $\begin{array}{c}\text { Heat conductive } \\
\text { coefficient } \\
(\mathrm{W} / \mathrm{m} \cdot \mathrm{K})\end{array}$ & $\begin{array}{c}\text { Dynamic } \\
\text { viscosity } \\
(\mathrm{Pa} \cdot \mathrm{s})\end{array}$ \\
\hline $50 \%$ EGW & 1071.11 & 3300 & 0.384 & 0.00339 \\
\hline Battery & 1924.9 & 1210 & $0.9 / 2.7 / 2.7$ & - \\
\hline Aluminium & 2719 & 871 & 202.4 & - \\
\hline Al-Plastic Film & 1390 & 460 & 66.6 & - \\
\hline
\end{tabular}

\section{RESULTS AND DISCUSSION}

Maximum temperature $\left(T_{\mathrm{m}}\right)$ is the maximum temperature value of cell at a certain moment, and the highest maximum temperature $\left(T_{\mathrm{H}}\right)$ is the highest value of the 30 maximum temperatures in a set of simulation data. The temperature difference $(\Delta T)$ is the difference between the maximum temperature and the minimum temperature of cell at a certain moment. Accordingly, the maximum temperature difference $\left(\Delta T_{\mathrm{m}}\right)$ is the highest value of the 30 temperature differences in a set of simulation data.

\subsection{Effects of cold plate inlet and outlet sizes on temperature}

According to Fig. 5, regardless of the cold plate size, the $T_{\mathrm{m}}$ of cell increases initially and then decreases. $T_{\mathrm{m}}$ is reached at a certain discharge time and is related to heat generation rate.
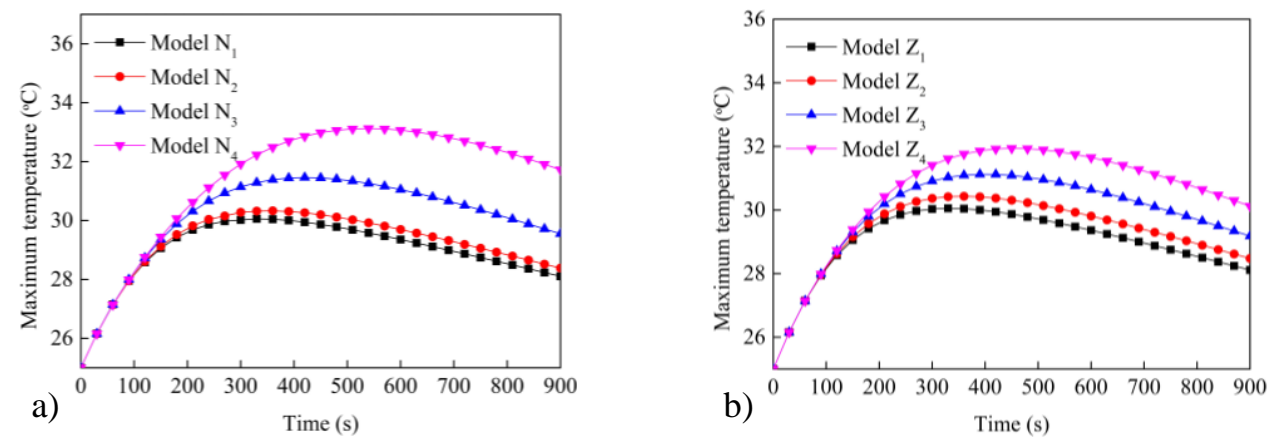

Figure 5: $T_{\mathrm{m}}$ of cells in Models $\mathrm{N}$ and $\mathrm{Z}$ with $d_{2}$ of $1 \mathrm{~mm}$.

In Fig. 5 a, the $T_{\mathrm{m}}$ of cells in $\mathrm{N}_{1}$ is $30.1^{\circ} \mathrm{C}$ at $330 \mathrm{~s}$ when $W$ is $0.01 \mathrm{~kg} / \mathrm{s}$. The cells in $\mathrm{N}_{2}$ reach $T_{\mathrm{m}}$ of $30.3{ }^{\circ} \mathrm{C}$ at $360 \mathrm{~s}$, with an increase in $0.2{ }^{\circ} \mathrm{C}$, compared with Model $\mathrm{N}_{1}$. When $d_{1}$ increases to $4 \mathrm{~mm}$, the cells in $\mathrm{N}_{3}$ reach $T_{\mathrm{m}}$ of $31.5^{\circ} \mathrm{C}$ at $420 \mathrm{~s}$, with an increase of $1.2^{\circ} \mathrm{C}$ compared with Model $\mathrm{N}_{2}$. The cells in Model $\mathrm{N}_{4}$ reach $T_{\mathrm{m}}$ of $33.1^{\circ} \mathrm{C}$ at $540 \mathrm{~s}, 1.6^{\circ} \mathrm{C}$ higher than that of Model $\mathrm{N}_{3}$. Evidently, $T_{\mathrm{m}}$ increases gradually with the increase in $\Delta d$, and the time for reaching $T_{\mathrm{m}}$ is gradually delayed. $T_{\mathrm{m}}$ in Model $\mathrm{N}$ appears at the cell's corners in Fig. 6 . The 
figure shows that as the thickness of cavity cold plate increases, the coolant flow at the four cold plate corners slows down. All $T_{\mathrm{m}}$ is below $34^{\circ} \mathrm{C}$.

In Fig. $5 \mathrm{~b}$, when $W$ is $0.01 \mathrm{~kg} / \mathrm{s}, T_{\mathrm{m}}$ in Model $\mathrm{Z}$ gradually increases with the increase in $\Delta d$. In addition, the time to reach $T_{\mathrm{m}}$ is gradually delayed. For instance, when $W$ is $0.01 \mathrm{~kg} / \mathrm{s}$, the cells in $\mathrm{Z}_{1}$ reach a $T_{\mathrm{m}}$ of $30.1^{\circ} \mathrm{C}$ at $330 \mathrm{~s}$, and the cells in $\mathrm{Z}_{2}$ reach a $T_{\mathrm{m}}$ of $30.4^{\circ} \mathrm{C}$ at $360 \mathrm{~s}$. The cells in $\mathrm{Z}_{4}$ reach a $T_{\mathrm{m}}$ of $31.9^{\circ} \mathrm{C}$ at $450 \mathrm{~s}$. All $T_{\mathrm{m}}$ is less than $32^{\circ} \mathrm{C}$. With the increase in $\Delta d$, the reason for the increase in $T_{\mathrm{m}}$ of Model $\mathrm{Z}$ is consistent with that in Model $\mathrm{N}$.

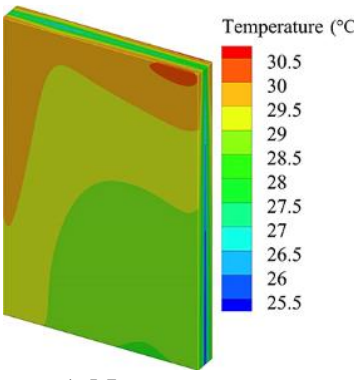

a) $\mathrm{N}_{1}$

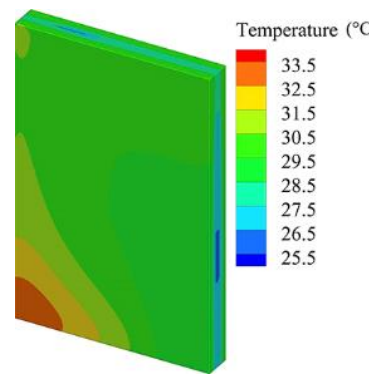

b) $\mathrm{N}_{4}$

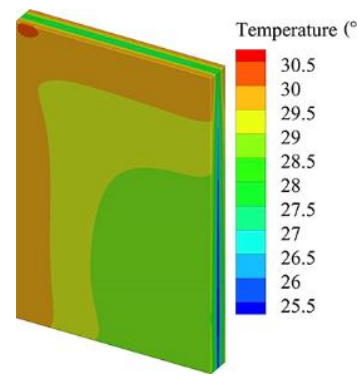

c) $\mathrm{Z}_{1}$

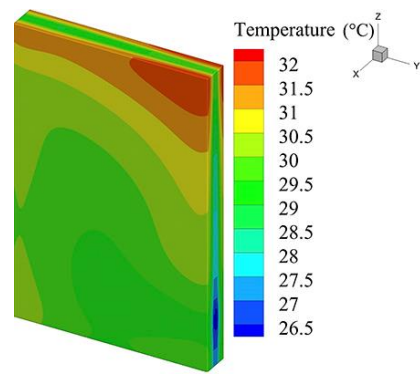

d) $\mathrm{Z}_{4}$

Figure 6: Temperature contours of different cooling system types with $W$ of $0.01 \mathrm{~kg} / \mathrm{s}$.

In Fig. 7, when $W$ is $0.01 \mathrm{~kg} / \mathrm{s}$, the cells in $\mathrm{N}_{5}$ reach a $T_{\mathrm{m}}$ of $30.3^{\circ} \mathrm{C}$ at $360 \mathrm{~s}, 0.2^{\circ} \mathrm{C}$ higher than that in $\mathrm{N}_{1}$. The cells in $\mathrm{N}_{6}$ reach a $T_{\mathrm{m}}$ of $30.6^{\circ} \mathrm{C}$ at $360 \mathrm{~s}, 0.3^{\circ} \mathrm{C}$ higher than that in $\mathrm{N}_{5}$. The cells in $\mathrm{N}_{7}$ reach a $T_{\mathrm{m}}$ of $30.9{ }^{\circ} \mathrm{C}$ at $420 \mathrm{~s}, 0.3^{\circ} \mathrm{C}$ higher than that in $\mathrm{N}_{5}$. In summary, when $W$ is $0.01 \mathrm{~kg} / \mathrm{s}$, with the increase in $d_{2}, T_{\mathrm{m}}$ in Model $\mathrm{N}$ gradually increases. And the time to reach $T_{\mathrm{m}}$ is gradually delayed. The increase in $T_{\mathrm{m}}$ is $0.2-0.3{ }^{\circ} \mathrm{C}$, because the increase in $d_{2}$ reduces the flow velocity at the cold plate inlet in the same $W$. The decrease in internal fluidity of the coolant in the cavity cold plate gradually increases the heat accumulation at the edge of the battery and $T_{\mathrm{m}}$. In Fig. $7 \mathrm{~b}$, when $W$ is $0.01 \mathrm{~kg} / \mathrm{s}$, the $T_{\mathrm{m}}$ of cells in Model $\mathrm{Z}$ gradually increases with the increase in $d_{2}$. The time to reach $T_{\mathrm{m}}$ is gradually delayed, and $T_{\mathrm{m}}$ is below $32^{\circ} \mathrm{C}$.
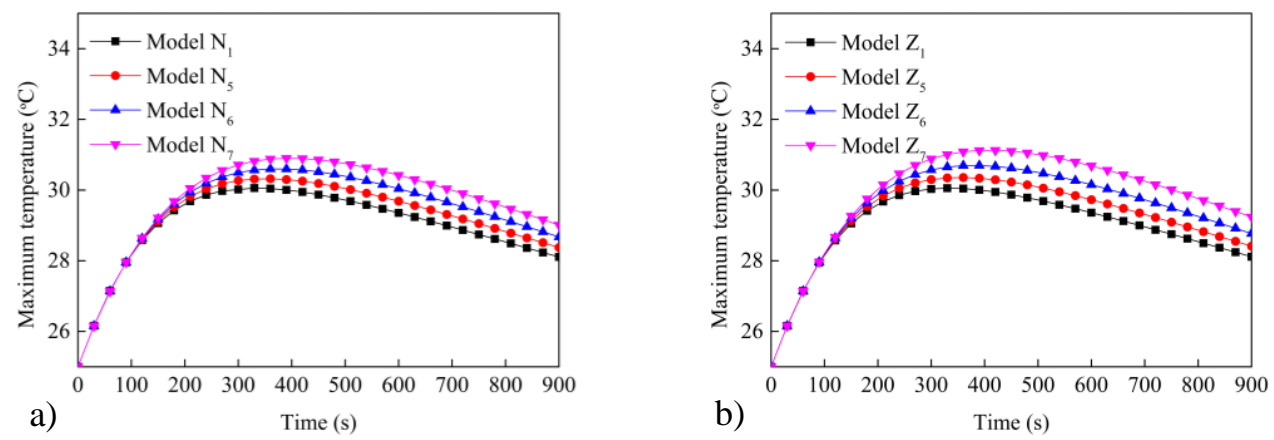

Figure 7: $T_{\mathrm{m}}$ of cells in Models $\mathrm{N}$ and $\mathrm{Z}$ with $\Delta d$ of $1 \mathrm{~mm}$.

$\Delta T$ shares similar rules with $T_{\mathrm{m}}$, as shown in Fig. 8 . When $W$ is $0.01 \mathrm{~kg} / \mathrm{s}$, the $\Delta T_{\mathrm{m}}$ of the cells in $\mathrm{N}_{1}$ is $4.4^{\circ} \mathrm{C}$, and the $\Delta T_{\mathrm{m}}$ in $\mathrm{N}_{2}$ is $4.6^{\circ} \mathrm{C}$; the increase is $0.2^{\circ} \mathrm{C}$. The $\Delta T_{\mathrm{m}}$ in $\mathrm{N}_{3}$ is $5.4^{\circ} \mathrm{C}$, and the increase is $0.8^{\circ} \mathrm{C} . \Delta T_{\mathrm{m}}$ in $\mathrm{N}_{4}$ is $6.7^{\circ} \mathrm{C}$, and the increase is $1.3^{\circ} \mathrm{C}$. In summary, the $\Delta T_{\mathrm{m}}$ of the cells gradually increases with the increase in $\Delta d$, and the increase is gradual. The reasons of $\Delta T$ rules are the same as those of $T_{\mathrm{m}}$. In Fig. $8 \mathrm{~b}$, the $\Delta T_{\mathrm{m}}$ of cells in Model $\mathrm{Z}$ gradually increases with the increase in $\Delta d$, which increases significantly with the increase in $\Delta d$. For example, when $W$ is $0.02 \mathrm{~kg} / \mathrm{s}$, the $\Delta T_{\mathrm{m}}$ in $\mathrm{Z}_{1}$ is $3.7^{\circ} \mathrm{C}$, and that in $\mathrm{Z}_{2}$ is $4.2^{\circ} \mathrm{C}$, with the increase of $0.5^{\circ} \mathrm{C}$. The $\Delta T_{\mathrm{m}}$ in $\mathrm{Z}_{3}$ is $5.0^{\circ} \mathrm{C}$, and the increase is $0.8{ }^{\circ} \mathrm{C}$. The $\Delta T_{\mathrm{m}}$ in $\mathrm{Z}_{4}$ is $6.4{ }^{\circ} \mathrm{C}$, and the increase is $1.4^{\circ} \mathrm{C}$. The reasons for the rules are the same as those of Model N.

In summary, the rules of the cells' $\Delta T$ agree with those of $T_{\mathrm{m}}$, that is, the increase in $\Delta T$ is gradual with the increase in $\Delta d$. When $d_{2}$ is $1 \mathrm{~mm}$ and $\Delta d$ is less than or equal to $2 \mathrm{~mm}, \Delta T_{\mathrm{m}}$ is 
less than $5{ }^{\circ} \mathrm{C}$ in Model $\mathrm{N}$ and Model $\mathrm{Z}$, thereby satisfying the requirements of battery heat dissipation.

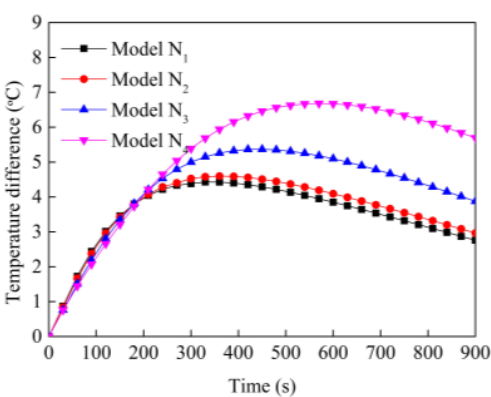

a) $W$ is $0.01 \mathrm{~kg} / \mathrm{s}$

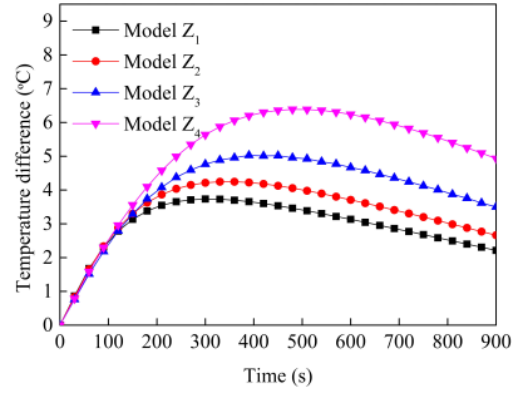

b) $W$ is $0.02 \mathrm{~kg} / \mathrm{s}$

Figure 8: $\Delta T$ of cells in Models $\mathrm{N}$ and $\mathrm{Z}$ with $d_{2}$ of $1 \mathrm{~mm}$.

In Fig. 9, when $W$ is $0.01 \mathrm{~kg} / \mathrm{s}$, the $\Delta T_{\mathrm{m}}$ values of cells in $\mathrm{N}_{5}, \mathrm{~N}_{6}$, and $\mathrm{N}_{7}$ are $4.6^{\circ} \mathrm{C}, 4.8^{\circ} \mathrm{C}$, and $5.0^{\circ} \mathrm{C}$, respectively. That is, with the increase in $d_{2}, \Delta T_{\mathrm{m}}$ gradually increases, and the increase is $0.2^{\circ} \mathrm{C}$. However, when $\Delta d$ is $1 \mathrm{~mm}$ and $W$ is $0.01 \mathrm{~kg} / \mathrm{s}$, the $\Delta T_{\mathrm{m}}$ in all Model $\mathrm{N}$ is less than $5^{\circ} \mathrm{C}$. In addition, except for $\mathrm{N}_{7}$, the cells' $\Delta T_{\mathrm{m}}$ in other cooling systems is less than $5^{\circ} \mathrm{C}$, thereby satisfying the requirements of BTMS. In Fig. $9 \mathrm{~b}$, when $W$ is $0.01 \mathrm{~kg} / \mathrm{s}, \Delta T_{\mathrm{m}}$ values of cells in $\mathrm{Z}_{1}, \mathrm{Z}_{5}, \mathrm{Z}_{6}$, and $\mathrm{Z}_{7}$ are $4.4{ }^{\circ} \mathrm{C}, 4.7^{\circ} \mathrm{C}, 4.9^{\circ} \mathrm{C}$, and $5.2^{\circ} \mathrm{C}$, respectively. The results show that with the increase in $d_{2}, \Delta T_{\mathrm{m}}$ in Model $\mathrm{Z}$ gradually increases by $0.2-0.3^{\circ} \mathrm{C}$. However, when $W$ is $0.01 \mathrm{~kg} / \mathrm{s}, \Delta T_{\mathrm{m}}$ of cells in Model $\mathrm{Z}$ with $d_{2}$ less than $4 \mathrm{~mm}$ is less than $5^{\circ} \mathrm{C}$.

In summary, although the $\Delta T_{\mathrm{m}}$ of cells in Model $\mathrm{N}$ and Model $\mathrm{Z}$ gradually increases with the increase in $d_{2}$, the increase of $\Delta T$ is gradual with $\Delta d$ of $1 \mathrm{~mm}$. Both system types can control $\Delta T$ to satisfy the thermal management requirements of less than $5^{\circ} \mathrm{C}$.
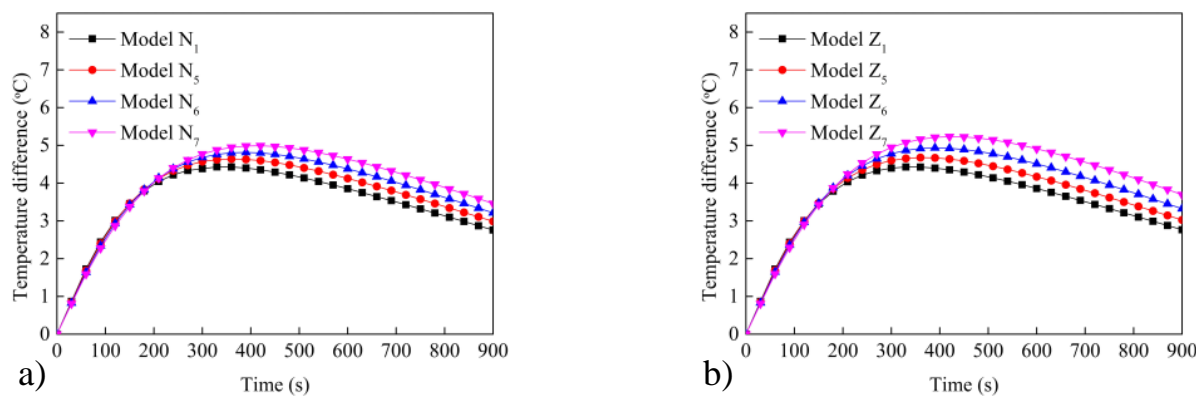

Figure 9: $\Delta T$ in Models $\mathrm{N}$ and $\mathrm{Z}$ with $\Delta d$ of $1 \mathrm{~mm}$.

\subsection{Effects of coolant mass flow rate on temperature}

In Fig. 10, when $W$ is 0.005 and $0.01 \mathrm{~kg} / \mathrm{s}, T_{\mathrm{m}}$ in Model $\mathrm{N}$ gradually increases with the increase in $\Delta d$. The increase in temperature with $W$ of $0.01 \mathrm{~kg} / \mathrm{s}$ is greater than that with $W$ of $0.005 \mathrm{~kg} / \mathrm{s}$. When $\Delta d$ increases to $4 \mathrm{~mm}\left(\mathrm{~N}_{4}\right), T_{\mathrm{H}}$ with $W$ of $0.005 \mathrm{~kg} / \mathrm{s}$ is $32.0^{\circ} \mathrm{C}$, which is $1.1^{\circ} \mathrm{C}$ lower than that with $W$ of $0.01 \mathrm{~kg} / \mathrm{s}$. In Fig. 11, the flow velocity with $W$ of $0.01 \mathrm{~kg} / \mathrm{s}$ in the area near the inlet and outlet is higher than that with $W$ of $0.005 \mathrm{~kg} / \mathrm{s}$ in $\mathrm{N}_{4}$. The area with higher flow velocity is more concentrated. The flow in the inner area of the lower left corner is worse. This condition causes heat to accumulate, and the cells' $T_{\mathrm{H}}$ is in this region. When $W$ is $0.015,0.02$, and $0.025 \mathrm{~kg} / \mathrm{s}, T_{\mathrm{H}}$ in Model $\mathrm{N}$ initially increases and then decreases with the increase in $\Delta d$. The extreme points of the $T_{\mathrm{H}}$ curves of the three conditions appear at the $\Delta d$ of $3 \mathrm{~mm}\left(\mathrm{~N}_{3}\right)$. In Model $\mathrm{N}$, when $d_{2}$ is $1 \mathrm{~mm}$, the slope of the $T_{\mathrm{H}}$ curve is different at different $d_{1}$ ranges. Thus, in different models, the order of $T_{\mathrm{H}}$ under different $W$ is different. For example, in $\mathrm{N}_{2}$, the $T_{\mathrm{H}}$ is $31.5^{\circ} \mathrm{C}$ when $W$ is $0.005 \mathrm{~kg} / \mathrm{s}$; in $\mathrm{N}_{3}, T_{\mathrm{H}}$ is $32.7^{\circ} \mathrm{C}$ when $W$ is $0.015 \mathrm{~kg} / \mathrm{s}$; in $\mathrm{N}_{4}$, the cells reach $T_{\mathrm{H}}$ when $W$ is $0.01 \mathrm{~kg} / \mathrm{s}$. The inlet and outlet with $d_{2}$ of $1 \mathrm{~mm}$ are small, and the flow velocity 
of the coolant varies greatly with different $W$ values. In addition, the flow field inside the cavity cold plate is more different. At the same time, the $\Delta d$ of the cavity cold plate increases. Therefore, the thickness of the fluid domain increases, thereby further increasing the difference in flow field. However, when $d_{2}$ is $1 \mathrm{~mm}$, the $T_{\mathrm{H}}$ of cells in Model $\mathrm{N}$ is less than $34{ }^{\circ} \mathrm{C}$ for a different $W$.
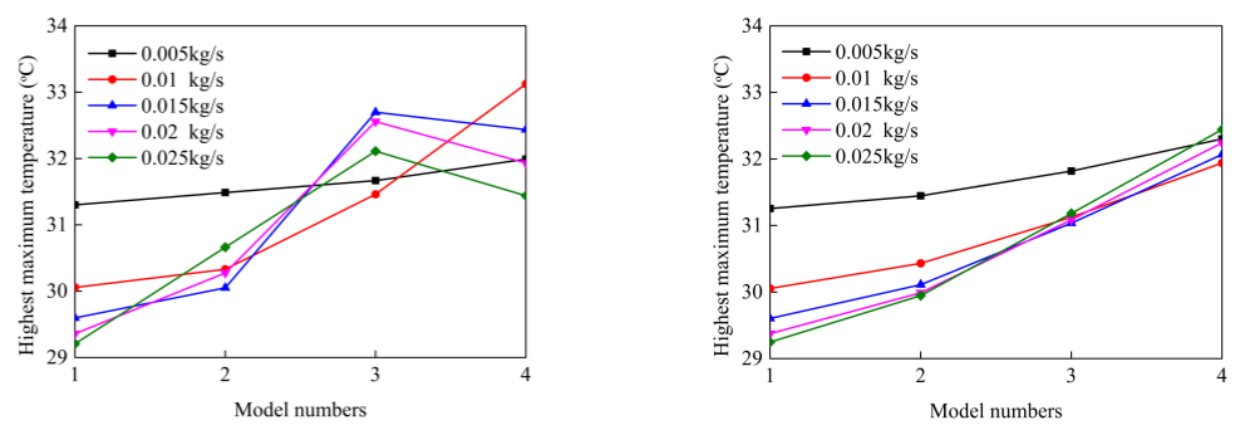

Figure 10: The cells $T_{\mathrm{H}}$ with different $W$ in Models $\mathrm{N}$ and $\mathrm{Z}$ with $d_{2}$ of $1 \mathrm{~mm}$, Model $\mathrm{N}$ on the left and Model $\mathrm{Z}$ on the right.

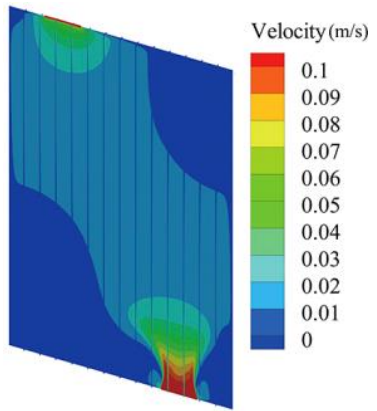

a) $\mathrm{N}_{4}, W$ is $0.005 \mathrm{~kg} / \mathrm{s}$

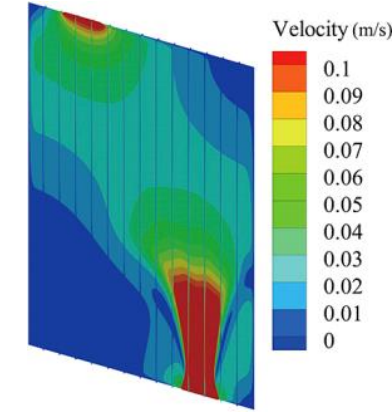

b) $\mathrm{N}_{4}, W$ is $0.01 \mathrm{~kg} / \mathrm{s}$

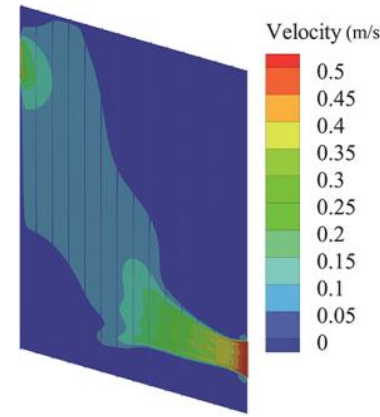

c) $\mathrm{Z}_{3}, W$ is $0.015 \mathrm{~kg} / \mathrm{s}$

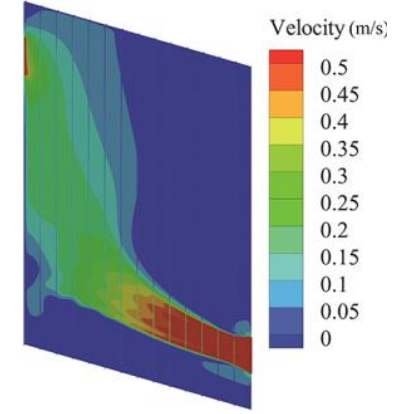

d) $\mathrm{Z}_{3}, W$ is $0.025 \mathrm{~kg} / \mathrm{s}$

Figure 11: Slices of flow velocity contours in cavity cold plate under different mass flow rates.

In Model Z, when $d_{2}$ is $1 \mathrm{~mm}$, the $T_{\mathrm{H}}$ of cells gradually increases with the increase in $\Delta d$. When $W$ is $0.005 \mathrm{~kg} / \mathrm{s}$, it increases from $31.3{ }^{\circ} \mathrm{C}$ in $\mathrm{Z}_{1}$ to $32.3^{\circ} \mathrm{C}$ in $\mathrm{Z}_{4}$, with an increase of $1{ }^{\circ} \mathrm{C}$. Similarly, when $W$ is $0.015 \mathrm{~kg} / \mathrm{s}$, the increase is $2.5^{\circ} \mathrm{C}$; when $W$ is $0.025 \mathrm{~kg} / \mathrm{s}$, the increase is $3.2^{\circ} \mathrm{C}$. In summary, the increase in $T_{\mathrm{H}}$ gradually increases with the increase in $W$. The reason is that when $W$ increases, the flow velocity of the coolant at inlet and outlet in Model $\mathrm{Z}$ increases, and the higher flow velocity area near the inlet and outlet is more concentrated. In addition, the thickness of the fluid domain increases, and the flow velocity at the corners away from the inlet and outlet decreases. Therefore, the temperature increases at that position. Moreover, the slope of the curves gradually increases with the increase in $W$. As a result, the order of $T_{\mathrm{H}}$ at different $W$ values and Model $\mathrm{Z}$ is different.

Fig. 12 shows the effects of different mass flow rates on the cells' $T_{\mathrm{m}}$ in Model $\mathrm{N}$ and Model $\mathrm{Z}$ when $\Delta d$ is $1 \mathrm{~mm}$. In Model $\mathrm{N}$, when $W$ is $0.005 \mathrm{~kg} / \mathrm{s}, T_{\mathrm{H}}$ increases from $31.3^{\circ} \mathrm{C}$ in $\mathrm{N}_{1}$ to $31.9^{\circ} \mathrm{C}$ in $\mathrm{N}_{7}$, with an increase of $0.6^{\circ} \mathrm{C}$. When $W$ is $0.01 \mathrm{~kg} / \mathrm{s}$, it increases by $0.8^{\circ} \mathrm{C}$ from $\mathrm{N}_{1}$ to $\mathrm{N}_{7}$. When $W$ is $0.015 \mathrm{~kg} / \mathrm{s}$, it increases by $1.6^{\circ} \mathrm{C}$ from $\mathrm{N}_{1}$ to $\mathrm{N}_{7}$. In addition, when $W$ is 0.02 and $0.025 \mathrm{~kg} / \mathrm{s}$, it increases by $2.4{ }^{\circ} \mathrm{C}$ and $3.3^{\circ} \mathrm{C}$, respectively. Evidently, with the increase in the mass flow rate at the cold plate inlet, the increase in $T_{\mathrm{H}}$ from $\mathrm{N}_{1}$ to $\mathrm{N}_{7}$ is gradual. Therefore, the slopes of the curves gradually increase with the increase in $W . \operatorname{In} \mathrm{N}_{1}$, with the increase in $W$, the $T_{\mathrm{H}}$ gradually decreases. The increase in $T_{\mathrm{H}}$ is gradual with the increase in $W$. Thus, $W$ with the highest temperature is different for different Model $\mathrm{N}$.

In Model Z, when $W$ is $0.005,0.01,0.015,0.02$, and $0.025 \mathrm{~kg} / \mathrm{s}$, the increase in $T_{\mathrm{H}}$ is $0.6^{\circ} \mathrm{C}$, $1.0{ }^{\circ} \mathrm{C}, 1.3{ }^{\circ} \mathrm{C}, 1.5^{\circ} \mathrm{C}$, and $1.8^{\circ} \mathrm{C}$, respectively. The $T_{\mathrm{H}}$ of cells gradually decreases with the increase in $W$, but the reduction gradually decreases. 

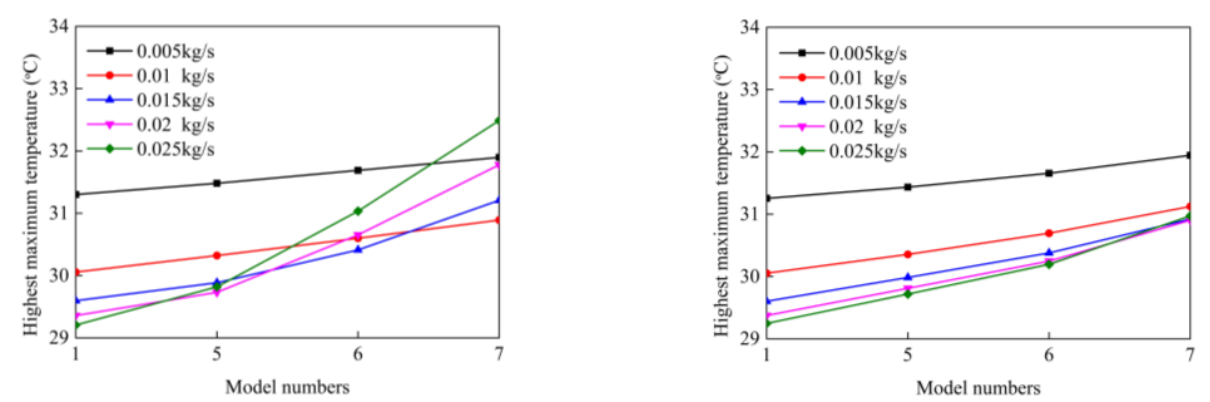

Figure 12: $T_{\mathrm{H}}$ with different $W$ in Models $\mathrm{N}$ and $\mathrm{Z}$ with $\Delta d$ of $1 \mathrm{~mm}$, Model $\mathrm{N}$ on the left and Model $\mathrm{Z}$ on the right.

In Fig. 13, the rules of $\Delta T_{\mathrm{m}}$ are related to those of $T_{\mathrm{H}}$. In Model $\mathrm{N}$, when $W$ is $0.005 \mathrm{~kg} / \mathrm{s}$, the $\Delta T_{\mathrm{m}}$ of cells in the four Models of $\mathrm{N}$ is greater than $5{ }^{\circ} \mathrm{C}$. When $W$ is greater than or equal to $0.01 \mathrm{~kg} / \mathrm{s}$, the $\Delta T_{\mathrm{m}}$ in $\mathrm{N}_{1}$ and $\mathrm{N}_{2}$ is less than $5{ }^{\circ} \mathrm{C}$, thereby satisfying the requirements of battery cooling systems. However, when $\Delta d$ is increased to 3 and $4 \mathrm{~mm}\left(\mathrm{~N}_{3}\right.$ and $\left.\mathrm{N}_{4}\right), \Delta T_{\mathrm{m}}$ is greater than $5^{\circ} \mathrm{C}$ with different $W$. In Model $\mathrm{Z}$, the rules of $\Delta T_{\mathrm{m}}$ are the same as $T_{\mathrm{H}}$. When $W$ increases, the slope of the curves gradually increases. Similarly, when $W$ is $0.005 \mathrm{~kg} / \mathrm{s}$, the $\Delta T_{\mathrm{m}}$ in the four Models of $\mathrm{Z}$ is greater than $5{ }^{\circ} \mathrm{C}$. In $\mathrm{Z}_{1}$ and $\mathrm{Z}_{2}$, when $W$ is greater than or equal to $0.01 \mathrm{~kg} / \mathrm{s}$, they are less than $5^{\circ} \mathrm{C}$. In $Z_{3}$, when $W$ is $0.01,0.015$, and $0.02 \mathrm{~kg} / \mathrm{s}, \Delta T_{\mathrm{m}}$ is less than $5^{\circ} \mathrm{C}$. However, when $W$ is $0.025 \mathrm{~kg} / \mathrm{s}, \Delta T_{\mathrm{m}}$ is $5.1^{\circ} \mathrm{C}$. In $\mathrm{Z}_{4}$, it is greater than $5^{\circ} \mathrm{C}$ at any $W$.
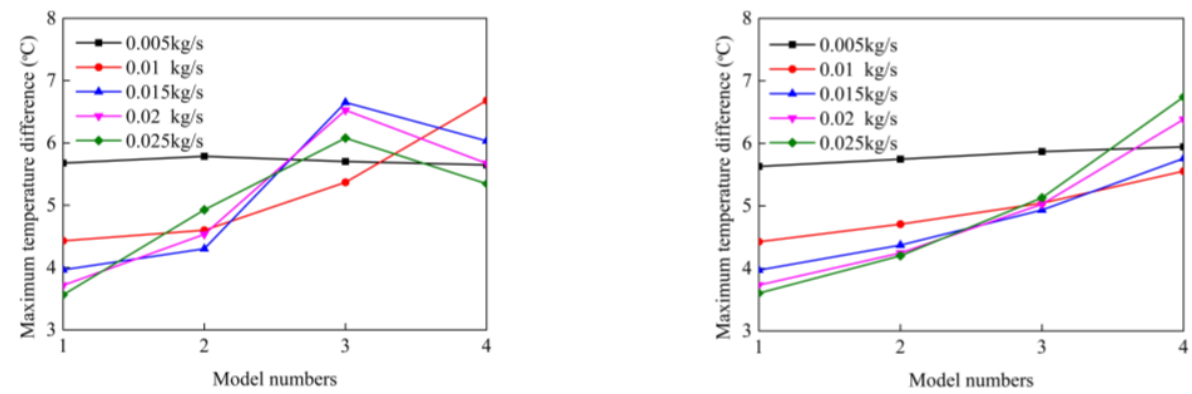

Figure 13: $\Delta T_{\mathrm{m}}$ of cells with different $W$ in Models $\mathrm{N}$ and $\mathrm{Z}$ with $d_{2}$ of $1 \mathrm{~mm}$, Model $\mathrm{N}$ on the left and Model $\mathrm{Z}$ on the right.

Fig. 14 shows the effects of different mass flow rates on $\Delta T_{\mathrm{m}}$ in Model $\mathrm{N}$ and Model $\mathrm{Z}$ when $\Delta d$ is $1 \mathrm{~mm}$. In Model $\mathrm{N}$, when $W$ is $0.005 \mathrm{~kg} / \mathrm{s}$, those in Model $\mathrm{N}$ with $\Delta d$ of $1 \mathrm{~mm}$ are greater than $5^{\circ} \mathrm{C}$. However, when $W$ is $0.01 \mathrm{~kg} / \mathrm{s}, \Delta T_{\mathrm{m}}$ in all Models of $\mathrm{N}$ with $\Delta d$ of $1 \mathrm{~mm}$ is less than $5^{\circ} \mathrm{C}$. When $W$ is 0.015 and $0.02 \mathrm{~kg} / \mathrm{s}$ and $d_{2}$ is less than or equal to $3 \mathrm{~mm}\left(\mathrm{~N}_{1}, \mathrm{~N}_{5}\right.$, and $\left.\mathrm{N}_{6}\right)$, they are less than $5^{\circ} \mathrm{C}$. When $W$ is $0.025 \mathrm{~kg} / \mathrm{s}$ and $d_{2}$ is less than or equal to $2 \mathrm{~mm}\left(\mathrm{~N}_{1}\right.$ and $\left.\mathrm{N}_{5}\right), \Delta T_{\mathrm{m}}$ is less than $5^{\circ} \mathrm{C}$. Similarly, in Model Z, when $W$ is $0.005 \mathrm{~kg} / \mathrm{s}$, the $\Delta T_{\mathrm{m}}$ in Model $\mathrm{Z}$ with $\Delta d$ of $1 \mathrm{~mm}$ is greater than $5^{\circ} \mathrm{C}$. When $W$ is $0.01 \mathrm{~kg} / \mathrm{s}, Z_{7}$ is also greater than $5^{\circ} \mathrm{C}$. However, with a different $W$ value, the other $\Delta T_{\mathrm{m}}$ in Model $\mathrm{Z}$ with $\Delta d$ of $1 \mathrm{~mm}$ is less than $5^{\circ} \mathrm{C}$.
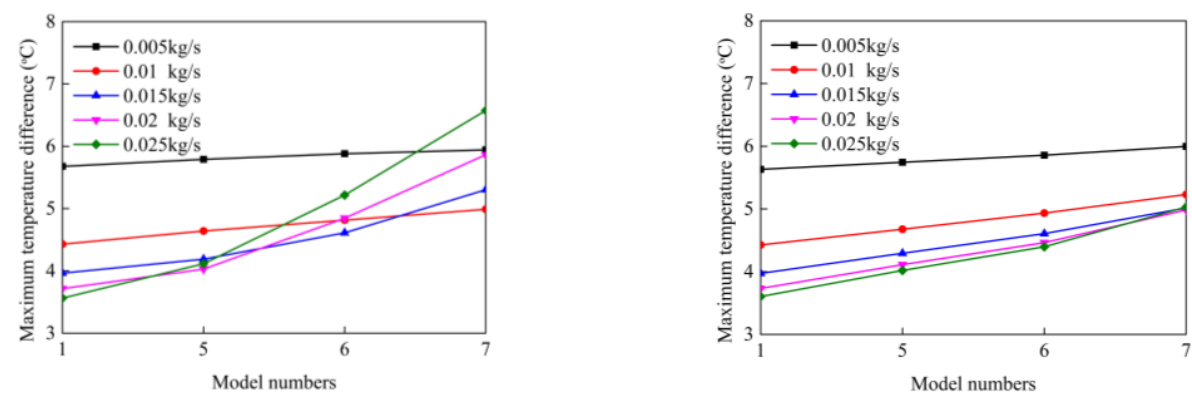

Figure 14: $\Delta T_{\mathrm{m}}$ of cells with different $W$ in Models $\mathrm{N}$ and $\mathrm{Z}$ with $\Delta d$ of $1 \mathrm{~mm}$, Model $\mathrm{N}$ on the left and Model $\mathrm{Z}$ on the right. 


\subsection{Effects of inlet and outlet positions on temperature}

By combining $W$ with different model types, two data groups of $35 T_{\mathrm{m}}$ and $\Delta T_{\mathrm{m}}$ in each group are generated, as shown in Figs. 15 and 16, respectively.

Fig. 15 shows the radars of $T_{\mathrm{H}}$ of the cells in the cavity cold plate cooling system of Model $\mathrm{N}$ and Model Z. Fig. 15 a shows that in Model $\mathrm{N}$, when $W$ is $0.01 \mathrm{~kg} / \mathrm{s}, T_{\mathrm{H}}\left(33.1^{\circ} \mathrm{C}\right)$ appears in $\mathrm{N}_{4}\left(d_{2}\right.$ is $\left.1 \mathrm{~mm}\right)$. When $W$ is $0.025 \mathrm{~kg} / \mathrm{s}$, the lowest $T_{\mathrm{m}}$ is $29.2^{\circ} \mathrm{C}$, which appears in $\mathrm{N}_{1}$. In addition, the $T_{\mathrm{H}}$ exceeding $32.5^{\circ} \mathrm{C}$ in Model $\mathrm{N}$ appears in $\mathrm{N}_{3}$ and $\mathrm{N}_{4}\left(d_{2}\right.$ is $\left.1 \mathrm{~mm}\right)$. In Fig. $15 \mathrm{~b}$, when $W$ is $0.025 \mathrm{~kg} / \mathrm{s}$, the $T_{\mathrm{H}}$ is $32.4{ }^{\circ} \mathrm{C}$ in $Z_{4}\left(d_{2}\right.$ is $\left.1 \mathrm{~mm}\right)$, and the lowest $T_{\mathrm{m}} 29.2{ }^{\circ} \mathrm{C}$ appears in $\mathrm{Z}_{1}$. The $T_{\mathrm{H}}$ exceeding $32{ }^{\circ} \mathrm{C}$ in Model $\mathrm{Z}$ appears in $\mathrm{Z}_{4}$. When the thickness of the cold plate is the same, the temperature curve circles with $\Delta d$ of $1 \mathrm{~mm}$ are closer to the centre point of the radar chart than that with $d_{2}$ of $1 \mathrm{~mm}$. In addition, by analysing all $T_{\mathrm{H}}$ values in Model $\mathrm{N}$ and Model $\mathrm{Z}$, the number of cases that $T_{\mathrm{H}}$ of different cold plate types appear in different temperature ranges in Table III is obtained. In Table III, compared with Model N, the $T_{\mathrm{H}}$ in Model $\mathrm{Z}$ has a lower temperature range and is not higher than $33^{\circ} \mathrm{C}$.

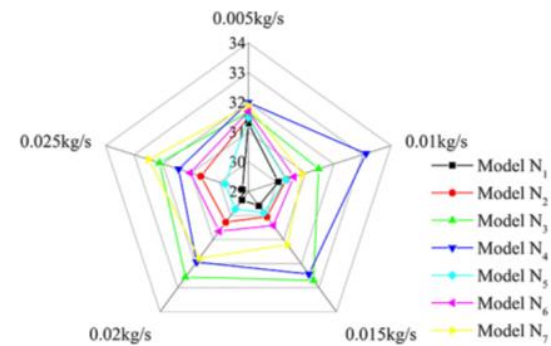

a) Model N

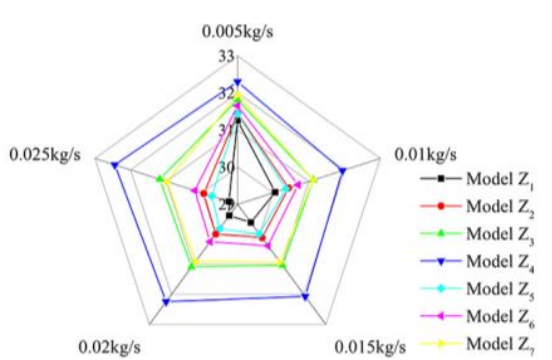

b) Model Z

Figure 15: Comparison of $T_{\mathrm{H}}$ in Models $\mathrm{N}$ and $\mathrm{Z}$.

Table III: The number of cases with $T_{\mathrm{H}}$ in different temperature ranges for different cold plate types.

\begin{tabular}{|c|c|c|}
\hline Temperature range $\left({ }^{\circ} \mathrm{C}\right)$ & Model N & Model Z \\
\hline $29-30$ & 6 & 8 \\
\hline $30-31$ & 10 & 11 \\
\hline $31-32$ & 13 & 12 \\
\hline $32-33$ & 5 & 4 \\
\hline $33-34$ & 1 & - \\
\hline
\end{tabular}

Fig. 16 shows radars of $\Delta T_{\mathrm{m}}$ in Model $\mathrm{N}$ and Model Z. $\Delta T_{\mathrm{m}}$ rules are similar to that of $T_{\mathrm{H}}$ because $\Delta T_{\mathrm{m}}$ is affected by $T_{\mathrm{H}}$. In Fig. $16 \mathrm{a}, \Delta T_{\mathrm{m}}$ is greater than $6^{\circ} \mathrm{C}$ in $\mathrm{N}_{3}, \mathrm{~N}_{4}$, and $\mathrm{N}_{7}$ cooling systems. When $W$ is $0.01 \mathrm{~kg} / \mathrm{s}, \Delta T_{\mathrm{m}} 6.7^{\circ} \mathrm{C}$ appears in $\mathrm{N}_{4}\left(d_{2}\right.$ is $\left.1 \mathrm{~mm}\right)$. When $W$ is $0.025 \mathrm{~kg} / \mathrm{s}$, the lowest $\Delta T_{\mathrm{m}} 3.6^{\circ} \mathrm{C}$ appears in $\mathrm{N}_{1}$. In Fig. $16 \mathrm{~b}$, only in $\mathrm{Z}_{4}, \Delta T_{\mathrm{m}}$ exceeds $6^{\circ} \mathrm{C}$. When $W$ is $0.025 \mathrm{~kg} / \mathrm{s}, \Delta T_{\mathrm{m}}$ is $6.7^{\circ} \mathrm{C}$. In $\mathrm{Z}_{1}$, when $W$ is $0.025 \mathrm{~kg} / \mathrm{s}$, the lowest $\Delta T_{\mathrm{m}}$ is $3.6^{\circ} \mathrm{C}$. Statistics show that, in Model $\mathrm{N}$ and Model Z, 16 and 18 cases, respectively, are required to obtain $\Delta T_{\mathrm{m}}$ of less than $5^{\circ} \mathrm{C}$. Similarly, when the cavity cold plate has the same thickness, the $\Delta T$ curve circles with $\Delta d$ of $1 \mathrm{~mm}$ are closer to the radar chart centre point than that with $d_{2}$ of $1 \mathrm{~mm}$.

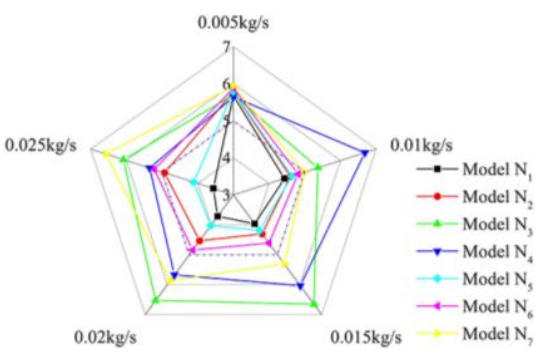

a) Model $\mathrm{N}$

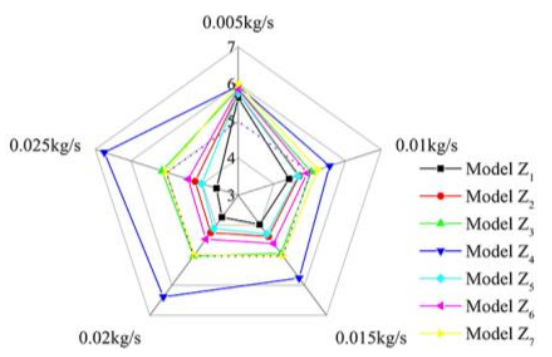

b) Model Z

Figure 16: Comparison of $\Delta T_{\mathrm{m}}$ in Models $\mathrm{N}$ and $\mathrm{Z}$. 


\section{CONCLUSION}

According to the experimental data of pouch Li-ion battery heat generation, an equivalent model of battery heat generation is established. The effects of inlet and outlet dimensions $\left(d_{2}\right.$ and $\Delta d$ ), coolant mass flow rate $(W)$, and inlet and outlet position (Model $\mathrm{N}$ and Model $\mathrm{Z}$ ) on the maximum temperature $\left(T_{\mathrm{m}}\right)$ and temperature difference $(\Delta T)$ of cells are studied using FLUENT 17.0. The conclusions are as follows:

(1) Inlet and outlet dimensions of cavity cold plate are positively correlated with $T_{\mathrm{m}}$ of cells. Under the same $W$, a change in $d_{2}$ or $\Delta d$ can control $\Delta T_{\mathrm{m}}$ within $5^{\circ} \mathrm{C}$.

(2) In Model $\mathrm{N}_{1}$ and Model $\mathrm{Z}_{1}, \Delta T_{\mathrm{m}}$ gradually decreases with the increase in $W$, but the decrease gradually reduces. By controlling inlet and outlet sizes and $W$, various cases can be achieved to satisfy the $\Delta T$ of less than $5^{\circ} \mathrm{C}$.

(3) Through comprehensive analysis of Model N and Model Z, Model Z cooling system can better control the maximum temperature and $\Delta T$ of cells in a reasonable range than Model $N$. At the same time, the cavity cold plate with inlet dimension $\Delta d$ of $1 \mathrm{~mm}$ has a better heat dissipation capacity than that of $d_{2}$ of $1 \mathrm{~mm}$.

In summary, a reasonable design of cavity cold plate and selection of coolant mass flow rate can satisfy the thermal management requirements of pouch Li-ion battery for vehicles. This research guides the design of cold plate.

\section{ACKNOWLEDGEMENT}

This study was supported by Key Research and Development Program of Shandong (Grant/Award Number: 2019SDZY01); Graduate Education Quality Improvement Program of Shandong Province (Grant/Award Number: SDYJD17018).

\section{REFERENCES}

[1] Akhoundzadeh, M. H.; Raahemifar, K.; Panchal, S.; Samadani, E.; Haghi, E.; Fraser, R.; Fowler, M. (2019). A conceptualized hydrail powertrain: a case study of the Union Pearson Express route, World Electric Vehicle Journal, Vol. 10, No. 2, Paper 32, 14 pages, doi:10.3390/wevj10020032

[2] Liu, S.; Gong, D. (2014). Modelling and simulation on recycling of electric vehicle batteries-using agent approach, International Journal of Simulation Modelling, Vol. 13, No. 1, 79-92, doi:10.2507/IJSIMM13(1)CO1

[3] Park, S. H.; Park, J.; Ryou, M.-H.; Lee, Y. M. (2020). Sensitivity of power of lithium-ion batteries to temperature: a case study using cylindrical- and pouch-type cells, Journal of Power Sources, Vol. 465, Paper 228238, 7 pages, doi:10.1016/j.jpowsour.2020.228238

[4] Huang, Z. H.; Zhao, C. P.; Li, H.; Peng, W.; Zhang, Z.; Wang, Q. (2020). Experimental study on thermal runaway and its propagation in the large format lithium ion battery module with two electrical connection modes, Energy, Vol. 205, Paper 117906, 16 pages, doi:10.1016/ j.energy.2020.117906

[5] Lv, Y.; Liu, G.; Zhang, G.; Yang, X. (2020). A novel thermal management structure using serpentine phase change material coupled with forced air convection for cylindrical battery modules, Journal of Power Sources, Vol. 468, Paper 228398, 9 pages, doi:10.1016/ j.jpowsour.2020.228398

[6] Xie, Y.; He, X.; Li, W.; Zhang, Y.; Dan, D.; Lee, K.; Liu, J. (2020). A novel electro-thermal coupled model of lithium-ion pouch battery covering heat generation distribution and tab thermal behaviours, International Journal of Energy Research, Vol. 44, No. 14, 11725-11741, doi:10.1002/er.5803

[7] Cen, J.; Jiang, F. (2020). Li-ion power battery temperature control by a battery thermal management and vehicle cabin air conditioning integrated system, Energy for Sustainable Development, Vol. 57, 141-148, doi:10.1016/j.esd.2020.06.004 
[8] Karimi, D.; Behi, H.; Jaguemont, J.; Sokkeh, M. A.; Kalogiannis, T.; Hosen, M. S.; Berecibar, M.; van Mierlo, J. (2020). Thermal performance enhancement of phase change material using aluminum-mesh grid foil for lithium-capacitor modules, Journal of Energy Storage, Vol. 30, Paper 101508, 12 pages, doi:10.1016/j.est.2020.101508

[9] Saw, L. H.; Poon, H. M.; Thiam, H. S.; Cai, Z. S.; Chong, W. T.; Pambudi, N. A.; King, Y. J. (2018). Novel thermal management system using mist cooling for lithium-ion battery packs, Applied Energy, Vol. 223, 146-158, doi:10.1016/j.apenergy.2018.04.042

[10] Wang, F. X.; Cao, J. H.; Ling, Z. Y.; Zhang, Z. G.; Fang, X. M. (2020). Experimental and simulative investigations on a phase change material nano-emulsion-based liquid cooling thermal management system for a lithium-ion battery pack, Energy, Vol. 207, Paper 118215, 11 pages, doi:10.1016/j.energy.2020.118215

[11] Ni, P. Y.; Wang, X. L. (2020). Temperature field and temperature difference of a battery package for a hybrid car, Case Studies in Thermal Engineering, Vol. 20, Paper 100646, 8 pages, doi:10.1016/j.csite.2020.100646

[12] Cho, G. Y.; Choi, J. W.; Park, J. H.; Cha, S. W. (2014). Transient modeling and validation of lithium ion battery pack with air cooled thermal management system for electric vehicles, International Journal of Automotive Technology, Vol. 15, No. 5, 795-803, doi:10.1007/s12239014-0083-X

[13] Xiao, C. R.; Zhang, G. Q.; Li, Z. H.; Yang, X. Q. (2020). Custom design of solid-solid phase change material with ultra-high thermal stability for battery thermal management, Journal of Materials Chemistry A, Vol. 8, No. 29, 14624-14633, doi:10.1039/d0ta05247g

[14] Putra, N.; Ariantara, B.; Pamungkas, R. A. (2016). Experimental investigation on performance of lithium-ion battery thermal management system using flat plate loop heat pipe for electric vehicle application, Applied Thermal Engineering, Vol. 99, 784-789, doi:10.1016/ j.applthermaleng.2016.01.123

[15] Wu, W. X.; Yang, X. Q.; Zhang, G. Q.; Chen, K.; Wang, S. F. (2017). Experimental investigation on the thermal performance of heat pipe-assisted phase change material based battery thermal management system, Energy Conversion and Management, Vol. 138, 486-492, doi:10.1016/j.enconman.2017.02.022

[16] Panchal, S.; Khasow, R.; Dincer, I.; Agelin-Chaab, M.; Fraser, R.; Fowler, M. (2017). Numerical modeling and experimental investigation of a prismatic battery subjected to water cooling, Numerical Heat Transfer, Part A: Applications, Vol. 71, No. 6, 626-637, doi: $10.1080 / 10407782.2016 .1277938$

[17] Fang, Y. D.; Shen, J. L.; Zhu, Y.; Ye, F.; Li, K.; Su, L. (2021). Investigation on the transient thermal performance of a mini-channel cold plate for battery thermal management, Journal of Thermal Science, Vol. 30, No. 3, 914-925, doi:10.1007/s11630-020-1280-8

[18] Li, M.; Wang, J. C.; Guo, Q.; Li, Y.; Xue, Q. F.; Qin, G. H. (2020). Numerical analysis of cooling plates with different structures for electric vehicle battery thermal management systems, Journal of Energy Engineering, Vol. 146, No. 4, Paper 04020037, 10 pages, doi:10.1061/(ASCE)EY.19437897.0000648

[19] Li, X. X.; Zhou, D. Q.; Zhang, G. Q.; Wang, C.; Lin, R. H.; Zhong, Z. D. (2019). Experimental investigation of the thermal performance of silicon cold plate for battery thermal management system, Applied Thermal Engineering, Vol. 155, 331-340, doi:10.1016/ j.applthermaleng.2019.04.007

[20] Huo, Y. T.; Rao, Z. H. (2015). The numerical investigation of nanofluid based cylinder battery thermal management using lattice Boltzmann method, International Journal of Heat and Mass Transfer, Vol. 91, 374-384, doi:10.1016/j.ijheatmasstransfer.2015.07.128

[21] Yang, X.-H.; Tan, S.-C.; Liu, J. (2016). Thermal management of Li-ion battery with liquid metal, Energy Conversion and Management, Vol. 117, 577-585, doi:10.1016/j.enconman.2016.03.054

[22] Al-Zareer, M.; Dincer, I.; Rosen, M. A. (2018). Heat and mass transfer modeling and assessment of a new battery cooling system, International Journal of Heat and Mass Transfer, Vol. 126, Part A, 765-778, doi:10.1016/j.ijheatmasstransfer.2018.04.157

[23] Zhang, X.; Wang, T.; Jiang, S. B.; Xu, H. G.; Zhang, Y. N. (2018). Modelling and simulation of pouch lithium-ion battery thermal management using cold plate, International Journal of Simulation Modelling, Vol. 17, No. 3, 498-511, doi:10.2507/IJSIMM17(3)449 